\title{
Larval and small juvenile cod Gadus morhua concentrated in the highly productive areas of a shelf break front
}

\author{
Peter Munk ${ }^{1, *}$, Per Olov Larsson ${ }^{2}$, Didrik Danielsen $^{3}$, Erlend Moksness ${ }^{3}$ \\ ${ }^{1}$ Danish Institute for Fisheries and Marine Research, Charlottenlund Castle, DK-2920 Charlottenlund, Denmark \\ ${ }^{2}$ Institute of Marine Research, PO Box 4, S-45 300 Lysekil, Sweden \\ ${ }^{3}$ Institute of Marine Research, Biological Station Floedevigen, N-4817 His, Norway
}

\begin{abstract}
The early life of cod was studied during a survey programme covering the northeastern North Sea, the Skagerrak and the Kattegat in May 1992. Our aim was to asses the interrelated effects of physical and biological factors on distribution, growth and survival of larval cod. In the present paper we describe the identified nursery areas of larvae/juveniles and analyse the connection between the distribution of cod and hydrographical (frontal) characteristics of the areas. A total area of $67000 \mathrm{~km}^{2}$ was covered by stations in a $10 \times 10$ nautical mile grid. Salinity, temperature, $\mathrm{NO}_{3}+\mathrm{NO}_{2}$ and chlorophyll concentration were profiled through the water column. Zooplankton were sampled by a submersible pump and abundance of fish larvae/juveniles were estimated by depth-integrating tows of a $2 \mathrm{~m}$ ring net. The hydrographical measurements indicated a shelf break front positioned along the shelf slope in the southern part of the investigation area, and within the zone of the front we observed enhanced primary production and abundance of both phyto- and zooplankton. The distribution of larval and juvenile cod was also related to the hydrography, the abundance of cod peaked within a restricted zone and the aggregations extended as a continuous band along the front. We suggest that the observed concurrence between a hydrographic front and cod larvae/juveniles is a general and recurrent phenomenon based on the spawning habits of cod and aggregation due to flow convergence at the front.
\end{abstract}

KEY WORDS: Gadus morhua - Larvae - Small juveniles - Nursery areas - Hydrographic fronts - Aggregation processes $\cdot$ North Sea and Skagerrak

\section{INTRODUCTION}

Distinct populations of cod Gadus morhua are found across the North Atlantic, spawning either in the neighbourhood of offshore banks (e.g. Browns Bank, Hurley \& Campana 1989; Georges Bank, Lough 1984) or in specific coastal areas (e.g. Lofoten area, Ellertsen et al. 1981; and off Iceland, Jonsson 1982). The nursery areas of the feeding stages are found some distance from the spawning locations; the displacement is determined by larval behaviour and the course of prevailing currents (e.g. Werner et al. 1993). Peak concentrations of cod larvae and juveniles are often observed above the shelf slopes (Lough 1984, Campana et al. 1989, Ellertsen et al. 1989), in zones where coastal

•E-mail: pm@dfu.min.dk water masses meet water of oceanic origin and where hydrographic fronts might be established (Moors et al. 1978). Thus, the observations of larval distribution indicate a linkage between the early life of cod and the hydrographic fronts at the shelf slope, a linkage comparable to the one shown for coastal tidal fronts and larvae of other fish species (e.g. Kiørboe et al. 1988, Doyle \& Ryan 1989, Munk 1993a).

In the present study we will explore this potential linkage at cod nursery areas in the northeastern part of the North Sea including the Skagerrak and Kattegat, an area where the shelf of the North Sea slopes towards the deep of the Norwegian Trench. The hydrography of this area is greatly influenced by a deep influx of Atlantic and North Sea water as well as by shallow coastal currents and hydrographic fronts might be established at the shelf slope (Rohde 1992). 


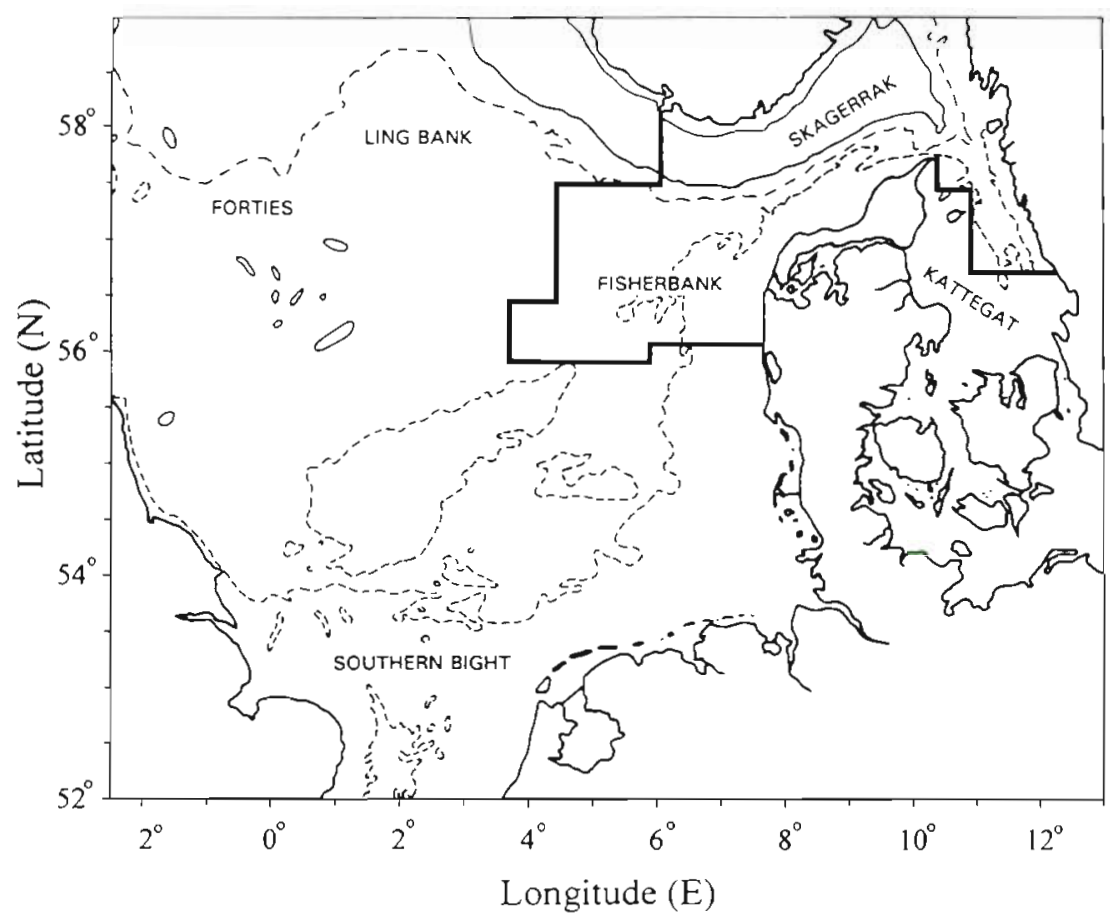

Fig. 1. The North Sea and adjacent waters. The area of investigation in the northeastern North Sea, Skagerrak and Kattegat is enclosed by full, heavy lines. Bottom topography is illustrated by the isobaths of $40 \mathrm{~m} \mathrm{(---)}, 100 \mathrm{~m}(---)$ and $200 \mathrm{~m}(-)$
The spawning sites of cod in the North Sea are well described (see Daan 1978, Brander 1994), whereas information on possible drift routes and location of specific nursery areas of the early stages are limited. Earlier studies (Graham \& Carruthers 1925, Poulsen 1931) indicate that eggs and larvae are advected from spawning sites in the northern-central areas towards nursery areas at the Fisher Banks and in the Skagerrak. In these studies the larger larvae and the juvenile cod were caught in highest numbers at areas of intermediate depth (between the 40 and $60 \mathrm{~m}$ isobaths).

In May 1992 we carried out an intensive survey programme in the northeastern North Sea, Skagerrak and Kattegat. The prime goal of the research was to ascertain the direct and indirect influence of hydrography on the distribution, growth and mortality of young cod, and ultimately gain insight into the causes of recruitment variability. A series of hydrographical and biological measurements were performed across the area of investigation. In this paper we examine the distinctness and characteristics of identified nursery areas of cod and evaluate the hypothesis predicting a unique coincidence between larval/juvenile distribution and a hydrographic front.

\section{MATERIALS AND METHODS}

Three research vessels were used in consecutive surveys during the period May 10 to 21, 1992. Each vessel covered a part of the $67000 \mathrm{~km}^{2}$ large investigation area (Fig. 1). Sampling was carried out in a 10 min (latitude), $20 \mathrm{~min}$ (longitude) grid. At sampling positions west of $9^{\circ} 55^{\prime} \mathrm{E}$, salinity, temperature and fluorescence were profiled $(0.5 \mathrm{~m}$ depth intervals) using a Neil Brown Mark III CTD with a mounted fluorometer. Chlorophyll concentration was estimated in 2 to 5 water samples at each station using procedures described in Nielsen et al. 1993 (west of $8^{\circ} 05^{\prime} \mathrm{E}$ ) or Jeffrey \& Humprey 1975 (east of $8^{\circ} 05^{\prime} \mathrm{E}$ ) and a relationship between chlorophyll a (chl a) concentration and fluorescence was established. The relationship was used to convert fluorescence profiles to a measure of chl a concentration through the water column. East of $9^{\circ} 55^{\prime} \mathrm{E}$ vertical CTD profiles were carried out at a restricted number of stations using water bottle sampling at every $5 \mathrm{~m}$ above $30 \mathrm{~m}$ depth and every $10 \mathrm{~m}$ below. The concentration of $\mathrm{NO}_{3}+\mathrm{NO}_{2}$ was measured as in Nielsen et al. (1993) at 10 or $25 \mathrm{~m}$ depth intervals and the primary production was estimated at stations west of $8^{\circ} 05^{\prime} \mathrm{E}$ using the methods described in Nielsen et al. (1993).

Zooplankton were collected with a submersible pump $\left(1.2 \mathrm{~m}^{3} \mathrm{~min}^{-1}\right)$ at 20 positions west of $8^{\circ} 05^{\prime} \mathrm{E}$. The pump was equipped with a $30 \mu \mathrm{m}$ conical net and when sampling it was raised from seabed to surface at a speed of $10 \mathrm{~m} \mathrm{~min}^{-1}$. Zooplankton were preserved in $4 \%$ formalin and later densities and biomass were esti. mated within size intervals as described in Kiørboe \& Nielsen (1990).

Larval/juvenile fish were sampled using a ring net of $2 \mathrm{~m}$ diameter. The basic design of the gear is illustrated 
in Munk (1993b). The gear has a 2-legged, $10 \mathrm{~m}$ long bridle and is equipped with a $13 \mathrm{~m}$ long black net of $1.6 \mathrm{~mm}$ mesh size. One of 2 types of depressors were used, either a $2 \mathrm{~m}$ long dihedral or a small saddleshaped type. At each station the gear was towed in an oblique haul sampling the water column to $5 \mathrm{~m}$ above the bottom. The gear was deployed and retrieved at wire speeds of 25 and $15 \mathrm{~m} \mathrm{~min}^{-1}$ respectively while speed of ship was kept at $1.5 \mathrm{~m} \mathrm{~s}^{-1}$. The volume of water filtered was estimated using a calibrated flowmeter in the centre of the net opening. All fish were preserved in $96 \%$ ethanol and were later identified to species and measured within $1 \mathrm{~mm}$ length intervals (standard length, SL). Densities of cod per unit surface area were estimated using filtered water volume and water depth. Catchability of larval/juvenile cod differed between day and night, and in the present calculations we account for this by converting the catches at day $\left(C_{\text {day }}\right)$ to an estimate of catch at night $\left(C_{\text {night }}\right)$ by the relationship assessed by Munk (1993b): $C_{\text {night }}=C_{\text {day }} /(1.19-0.029 \mathrm{SL})$, where $\mathrm{SL}=$ length class in $\mathrm{mm}, 7 \mathrm{~mm}<$ $\mathrm{SL}<35 \mathrm{~mm}$.

The interpolation between values, when preparing isopleths of results, followed a standard procedure as the one described in Munk (1993a).

\section{RESULTS}

A total of 196 stations were sampled across the area of investigation. The variation in hydrographical, chemical and biological parameters is exemplified by the 2 cross-shelf vertical sections shown in Figs. $2 \& 3$. These sections followed $6^{\circ} 40^{\prime} \mathrm{E}$ from $57^{\circ} 30^{\prime} \mathrm{N}$ to $56^{\circ} 10^{\prime} \mathrm{N}$ (left graphs of Figs. $2 \& 3$ ) and $8^{\circ} 40^{\prime} \mathrm{E}$ from $58^{\circ} \mathrm{N}$ to $57^{\circ} 10^{\prime} \mathrm{N}$ (right graphs of Figs. $2 \& 3$ ). Each section was sampled within a period of $5 \mathrm{~d}$. The salinity profiles (Fig. 2a, b) illustrate the extent of the coastal currents [Jutland Coastal Current (JCC) and Norwegian Coastal Current (NCC), Fig. 2b] overlaying the more saline water above the Norwegian Trench, and show the dispersal of watermasses influenced by the NCC across the central parts of Skagerrak. The isohalines were dome-shaped, raised towards the Danish coast, and the water column was completely mixed in the southern part of each section. Salinity of the upper watermasses declined from the North Sea areas through the Skagerrak into the Kattegat.

Watermasses north of the deepest part of the Norwegian Trench were generally less saline and colder than southern watermasses (Fig. 2b, d). At the shelf slope in the southern part of the study area (at isobaths of 50 to $80 \mathrm{~m})$ an upwelling of relatively cold water $\left(<7.6^{\circ} \mathrm{C}\right)$ was observed (Fig. 2c, d). This watermass was of the same high salinity $(>34.8 \%$ ) as the water in the central
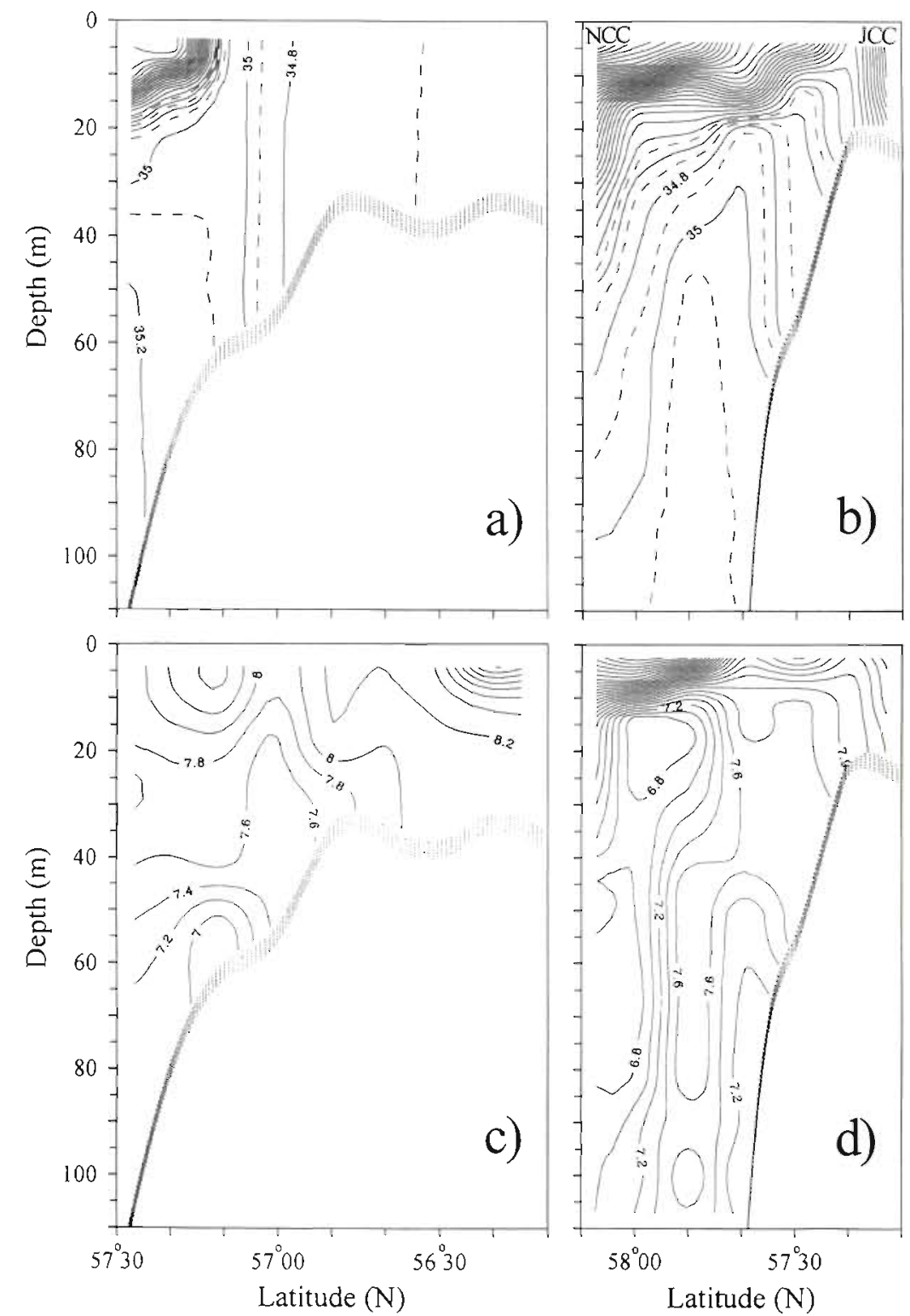

Fig. 2. Vertical profiles of salinity and temperature. Salinity along (a) $6^{\circ} 40^{\prime} \mathrm{E}$, isohalines increasing by $0.1 \%$, and (b) $8^{\circ} 40^{\prime} \mathrm{E}$, isohalines increasing by $0.1 \%$. The Norwegian Coastal Current (NCC) and the Jutland Coastal Current (JCC) are indicated. Temperature along (c) $6^{\circ} 40^{\prime} \mathrm{E}$, and (d) $8^{\circ} 40^{\prime} \mathrm{E}$, isotherms increasing by $0.2^{\circ} \mathrm{C}$ 

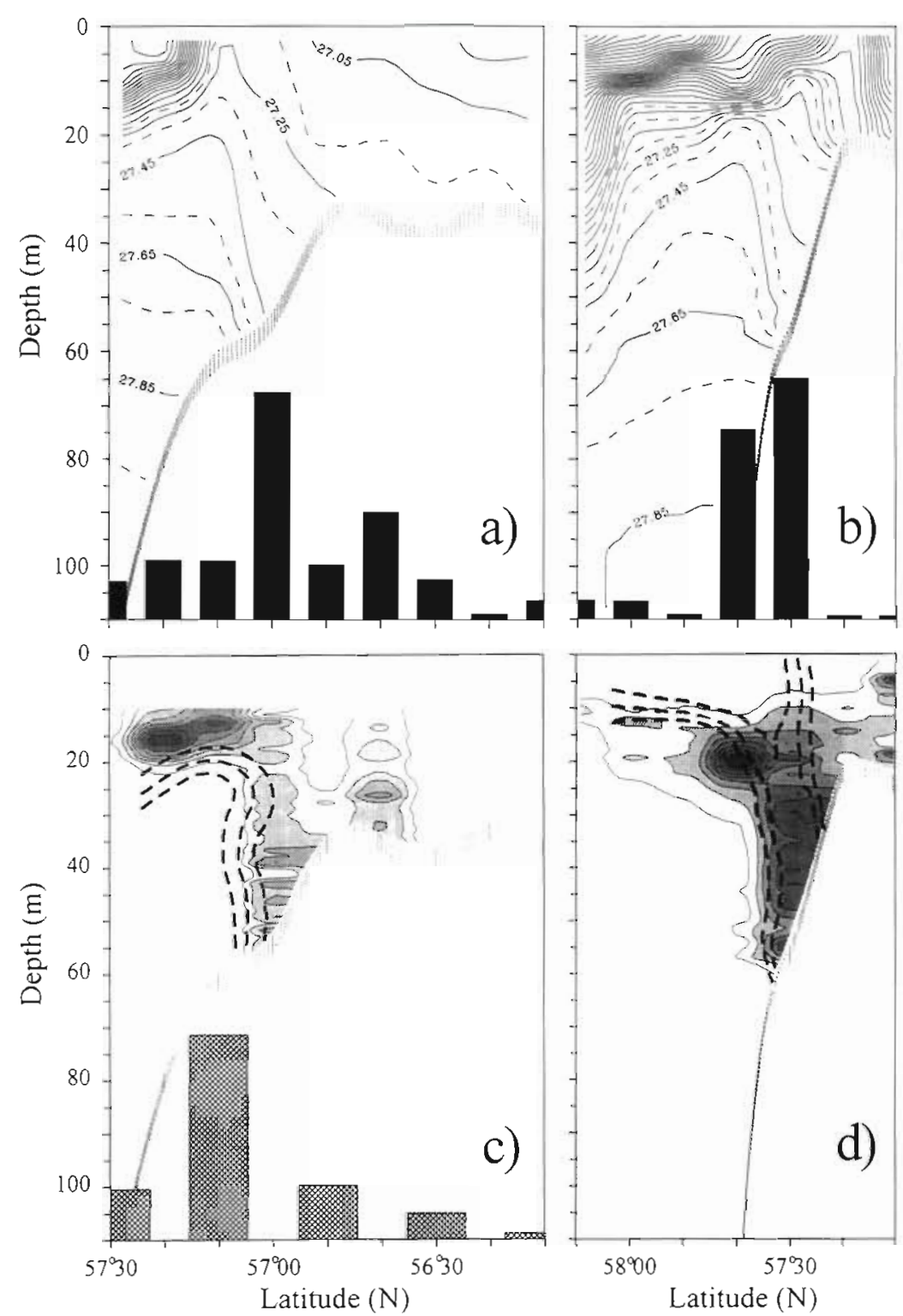

Fig. 3. Vertical profiles of water density and chlorophyll a content. (a) Section along $6^{\circ} 40^{\prime} \mathrm{E}$. Water density above $1000 \mathrm{~kg} \mathrm{~m}^{-3}$ illustrated by isocurves, increasing by $0.1 \mathrm{~kg} \mathrm{~m}^{-3}$, and concentration of cod illustrated by solid bars, in no. $\mathrm{m}^{-2}$, values read on axis to the right. (b) Section along $8^{\circ} 40^{\prime} \mathrm{E}$. Water density and cod concentration as for (a). (c) Section along $6^{\circ}$ $40^{\prime} \mathrm{E}$. Concentration of $\mathrm{chl} a$ illustrated by isocurves and shading, increasing by $1 \mathrm{mg} \mathrm{m}^{-3}$ (outermost line illustrate the $2 \mathrm{mg} \mathrm{m}^{-3}$ isoline); nutricline: heavy, broken isocurves of $0.5,1.0$ and $1.5 \mathrm{mg} \mathrm{NO}_{2}+\mathrm{NO}_{3}$ $\mathrm{m}^{-3}$ (outermost line illustrates the $1.5 \mathrm{mg} \mathrm{m}^{-3}$ isoline); primary production in $\mathrm{g} \mathrm{C} \mathrm{m}^{-2} \mathrm{~d}^{-1}$ : hatched bars values read on axis to the right. (d) Section along $8^{\circ} 40^{\prime} \mathrm{E}$. Chl a and $\mathrm{NO}_{2}+\mathrm{NO}_{3}$ concentration as for $\{c\}$ part of the Trench, above the deepest part. Differences in water density due to temperature, salinity and pressure (depth) are illustrated in Fig. 3a, b. The density structure was dominated by the salinity field. Isopycnals show a dome-shape across the Trench, and at the southern shelf slope (at 60 to $80 \mathrm{~m}$ isobaths) isopycnals declined abruptly, indicating a frontal zone. The horizontal extension of the area of elevated isopycnals and their abrupt decline is illustrated in Fig 4 by the depth of the isopycnal of $1027.45 \mathrm{~kg} \mathrm{~m}^{-3}$. In the eastern part of the Skagerrak the CTD-profiling was limited, constraining the delineation of a frontal zone here.

Fig. 3c, d shows the dynamics related to primary production. The nutricline is demarcated by the isolines of $0.5,1.0$ and $1.5 \mathrm{mg} \mathrm{m}^{-3} \mathrm{NO}_{2}+\mathrm{NO}_{3}$, the algal production ( $\mathrm{g} \mathrm{C} \mathrm{m}^{-2} \mathrm{~d}^{-1}$ ) is given by bars (Fig. $3 \mathrm{c}$ only) and the chl a concentration $\left(\mathrm{mg} \mathrm{m}^{-3}\right)$ is illustrated by shading. The findings indicate a peak in both production and abundance of algae just off the nutricline within the watermasses of low nutrients and in the areas where isopycnals decline at the southern shelf slope (compare to Fig. 3a, b). A comparison between the extent of the frontal zone, illustrated by Fig. 4 [steep decline of the isopycnal(s)], and the horizontal distribution of algal biomass and production, shown in Figs. $5 \& 6$ a respectively, gives further evidence of a connection between the frontal processes and the enhancement of primary production

The distribution of mesozooplankton was only surveyed west of $8^{\circ} 05^{\prime} \mathrm{E}$. The calanoid copepods dominated the mesozooplankton, densities of all sizes ranged from 4 to $26 \mathrm{I}^{-1}$. The larger specimens of cope- 
Fig. 4. Contouring of the depth ( $m$ below surface) of the isopycnal $1027.45 \mathrm{~kg} \mathrm{~m}^{-3}$ Isocurves and shading are shown for intervals of $5 \mathrm{~m}$ as given by the inserted scale. (A) Sampling positions
Fig. 5. Contouring of depth integrated chl a concentration. Isocurves and shading are shown for intervals of $25 \mathrm{mg} \mathrm{m}^{-2}$ as given by the inserted scale. (4) Sampling positions
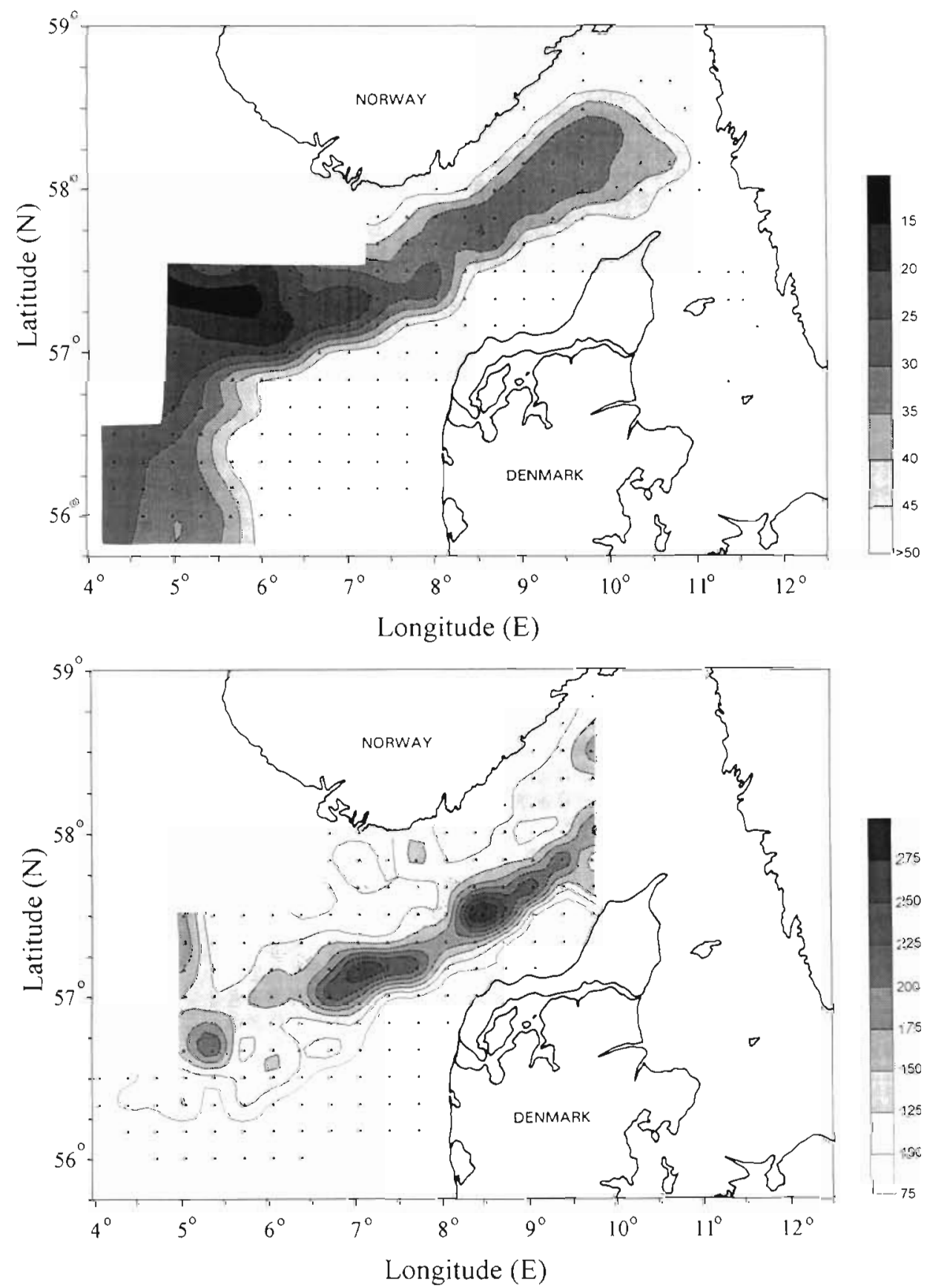

pods were found at somewhat lower densities, e.g. copepods longer than $400 \mu \mathrm{m}$ (cephalothorax length) were found at densities ranging from 1 to $7 \mathrm{l}^{-1}$. The larger copepods, which accounted for most of the biomass, were the preferred prey of the cod larvae/juveniles sampled during the present investigation ( $P$. Munk unpubl. results). Fig. 6b shows the variation in copepod biomass across the area whereas Fig. 6c-f illustrates the distribution pattern of the species of major importance: Calanus finmarchicus, Temora longicornis, Pseudocalanus elongatus and Acartia sp. The areas of high biomass differed somewhat between these copepod species, however, the biomass of $C$. finmarchicus was dominant. The general pattern observed was enlarged copepod biomass in the zone between the 50 and $60 \mathrm{~m}$ isobaths which coincides with the location of the hydrographic front.

The variation in the concentration of cod along transects is illustrated in Fig. 3a, b by the inserted bars. The concentration of cod peaked in the area of inclining pycnolines, reaching $1.2 \mathrm{~m}^{-2}$ along these 2 transects. Fig. 7 illustrates the distribution of cod across the entire sampling area. Cod were sampled at almost all stations, but the high concentrations were found in a 
band extending from the North Sea along the southern shelf slope into Skagerrak. This band followed the 55 to $75 \mathrm{~m}$ isobaths in the northwestern areas, whereas peak stations in the inner Skagerrak followed the 80 to $140 \mathrm{~m}$ isobaths. Larval peak abundance apparently coincide with the zone of the inclining pycnolines (compare Figs. $4 \& 7$ ). The coincidence is analysed statistically by a test of the null hypothesis that the abundance estimates within the frontal zone are not different from the estimates outside the zone. Only distributions south and east of the Trench are investigated and the zone of a marked inclination of pycnolines is arbitrary set to the zone where the pycnoline of $1027.45 \mathrm{~kg} \mathrm{~m}^{-3}$ inclines from 48 to $34 \mathrm{~m}$. The means of larval abundance estimates within and outside this zone are compared by an analysis of variance. The means are significantly different at $p<0.001$ and the hypothesis is rejected.
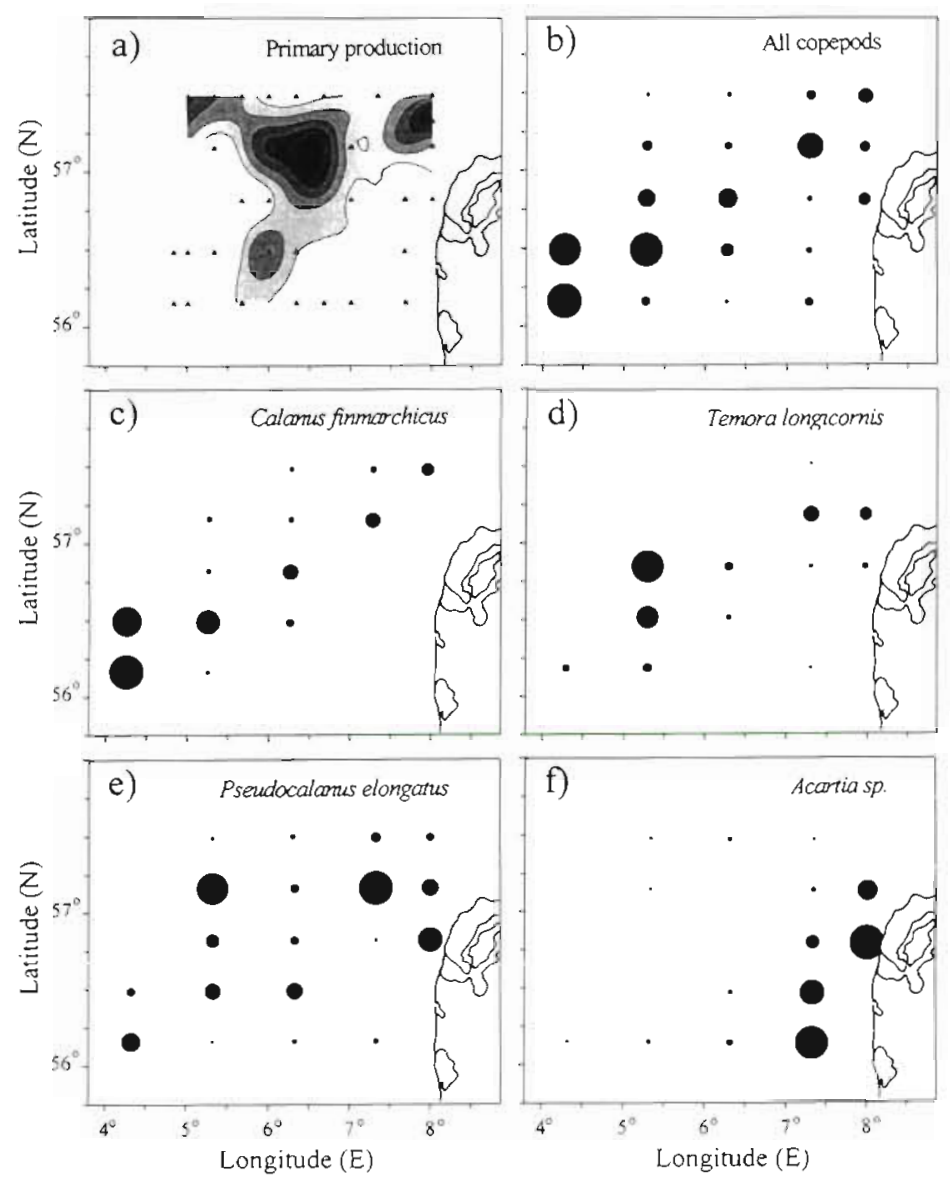

Fig. 6. Primary production and copepod biomass across the investigated area west of $8^{\circ} 05^{\prime} \mathrm{E}$. (a) Primary production in $\mathrm{g} \mathrm{C} \mathrm{m}^{-2} \mathrm{~d}^{-1}$, lightest shading illustrates 0.8 to $1.2 \mathrm{~g} \mathrm{C} \mathrm{m}^{-2} \mathrm{~d}^{-1}$ and isocurves increase by $0.4 \mathrm{~g} \mathrm{C} \mathrm{m}^{-2} \mathrm{~d}^{-1}$. (b) Total biomass of copepods, diameter of filled circles increases linearly from 0 to maximal size in the range of 0 to $6.8 \mathrm{~g}$ dry weight $\mathrm{m}^{-2}$ ( $\mathrm{c}$ to f) Biomass of different species of copepods. Diameter of filled circles increases linearly, maximal sizes are reached at (c) 6.0, (d) 1.6, (e) 0.4 and (f) $0.5 \mathrm{~g}$ dry weight $\mathrm{m}^{-2}$
The cod covered a wide range of sizes and stages of development. The development of adult characters is gradual and there is no sharp boundary between the larval and juvenile stages (Schmidt 1905). At a length of 20 to $25 \mathrm{~mm}$ cod has attained most of the permanent characters, the unpaired fins have obtained their full number of rays and the dorsal and anal fins are fully separated. According to Schmidt (1905) these fish would be juveniles. Most of the $\operatorname{cod}(78 \%)$ were of lengths ranging from 10 to $25 \mathrm{~mm}$, but specimens as small as $5 \mathrm{~mm}$ and as long as $41 \mathrm{~mm}$ were caught. In a single sample the range was on the order of $15 \mathrm{~mm}$. Lengths are given as standard length of preserved specimen, shrinkage by preservation was measured for 18 individuals and a mean shrinkage of $86 \%$ was estimated. Mean lengths at stations were calculated and in Fig 8 the size variation across the investigation area is illustrated. The Kattegat larvae were all relatively short and showed no obvious trend in mean length variation, whereas the mean length of larvae in the other areas showed a minimum along a line from the northwestern part to the northeastern part of the investigation area (Fig. 8). The minima were generally found offshore from peak concentrations of larvae. This is illustrated by Fig. 9a, b where mean lengths of cod are related to bathymetry for a northwestern area (between $57^{\circ} 10^{\prime} \mathrm{N}$ and $57^{\circ} 30^{\prime} \mathrm{N}$, west of $8^{\circ} \mathrm{E}$ ) and a northeastern area (between $58^{\circ} \mathrm{N}$ and $58^{\circ} 30^{\prime} \mathrm{N}$, east of $\left.10^{\circ} \mathrm{E}\right)$ respectively.

\section{DISCUSSION}

Our findings showed evidence of a relationship between hydrography, i.e. the frontal zone and distributional characteristics at 3 trophic levels: the production and abundance of unicellular algae, the abundance of copepods and finally the abundance of larval/juvenile cod. Apparently, in the present area of investigation, the nursery grounds of cod have outstanding characteristics and are highly productive in relation to the surrounding areas.

\section{The shelf break front}

The hydrographic front at the southern slope had characteristics of a shelf break front of the retrograde type, i.e. frontal isopleths were opposite to cross-shelf topography. The 'shelf break fronts' comprise the hydrographic fronts found at the zone of abrupt 
Fig. 7. Gadus morhua. Contours of larval/juvenile concentration. Isocurves and shading are shown for intervals of $0.3 \mathrm{~m}^{-2}$ as given by the inserted scale. (4) Sampling positions

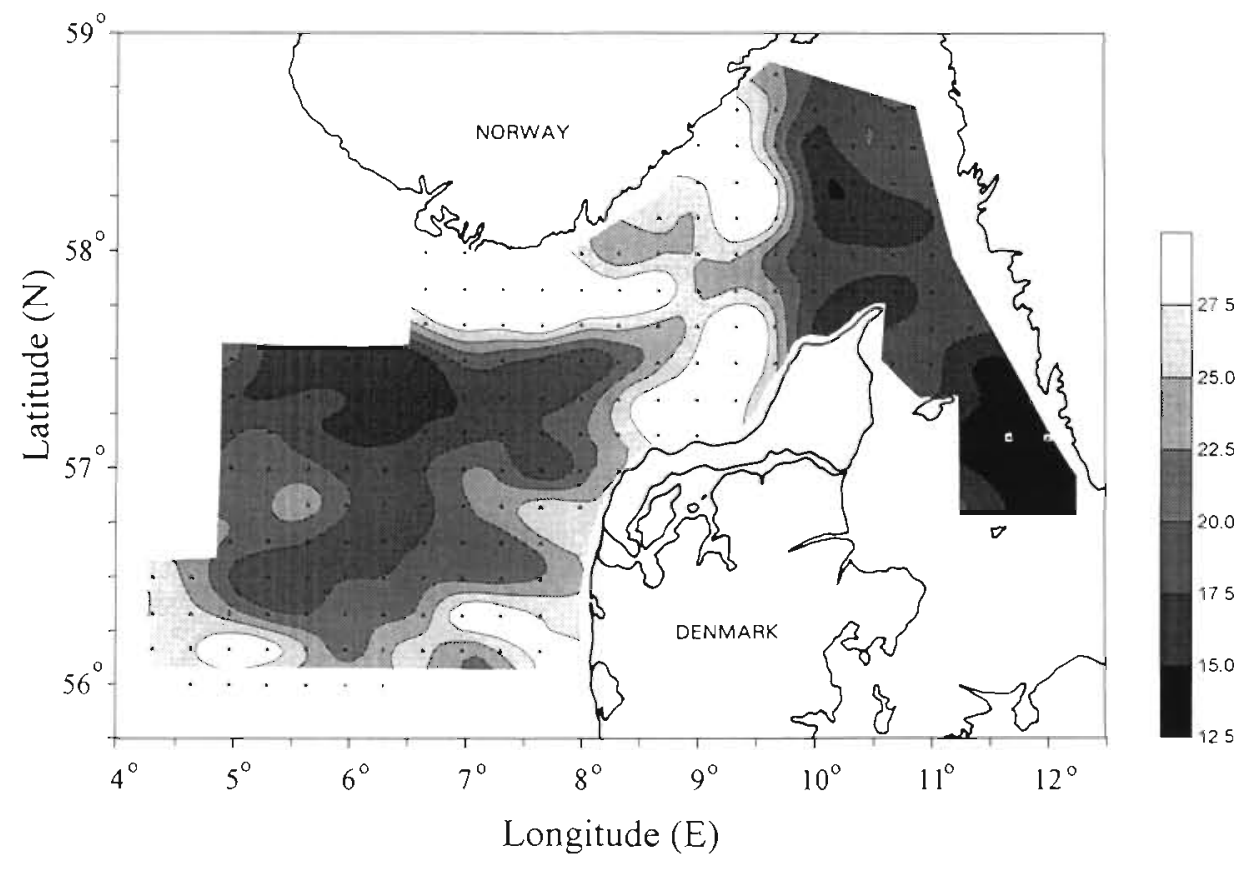

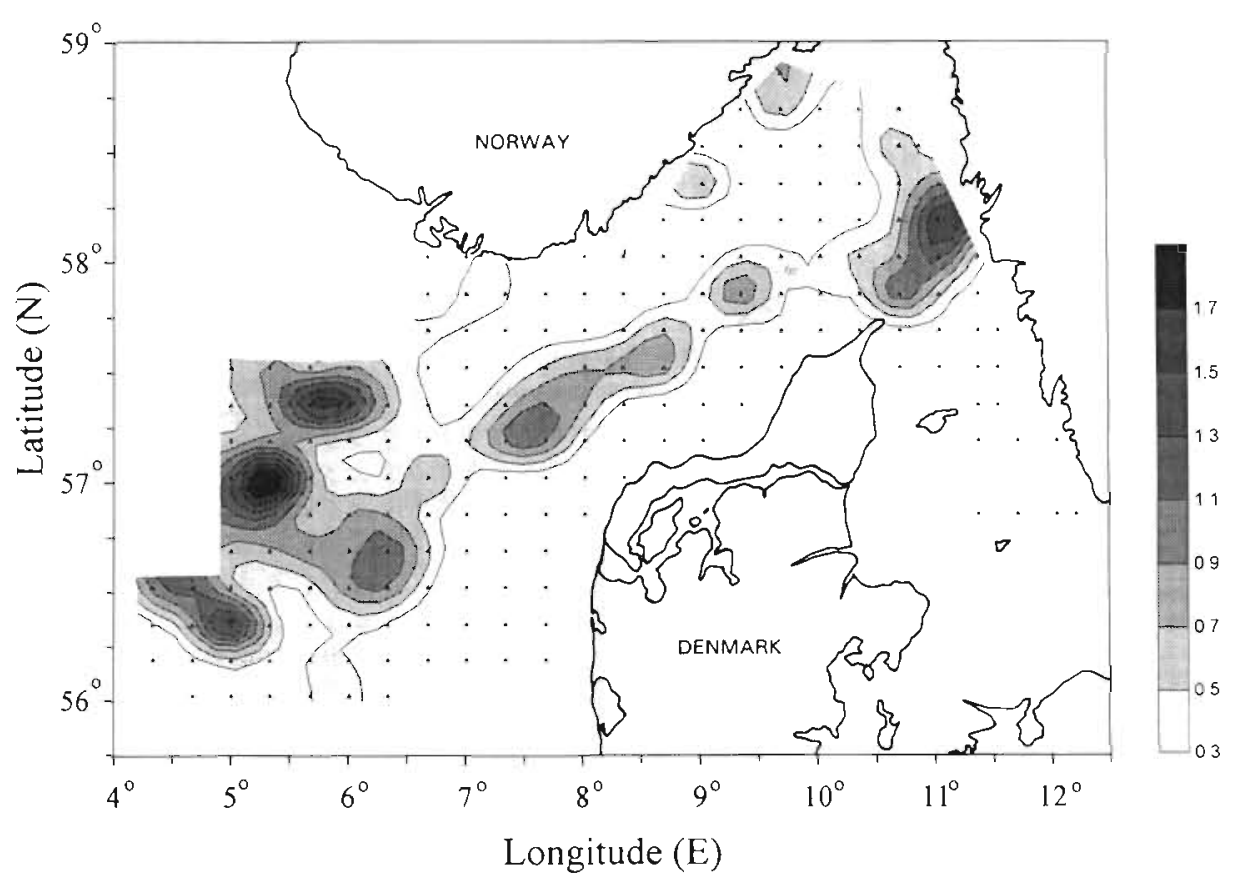

Fig. 8. Gadus morhua. Contours of mean length of sampled larvae/juveniles. Isocurves and shading are shown for intervals of $2.5 \mathrm{~mm}$ as given by the inserted scale. (4) Sampling positions increase in bottom slope marking a transition from the shelf to upper continental slope (Moors et al. 1978). In cases of a shallow position of the fronts these have been named shelf/slope water fronts (Moors et al. 1978, Herman et al. 1981) or middle fronts (Coachman 1982). Our observations in the Skagerrak showed a frontal position at the steep part of the slope (at about $120 \mathrm{~m}$ isobath) whereas in the North Sea the position of the front was somewhat shallower and its route more complex. A demarcation of a clear frontal zone was especially difficult around the shallow banks of the North Sea area.

Moors et al. (1978) and Marra et al. (1990) describe how the sharp winter density fronts can be modified in the spring by the increasing temperature and the decreasing salinity of the upper watermasses. The front identified in the present study was probably in a transition phase as the temperature of surface water was increasing significantly during the period of investigation. This is supported by observations made later 

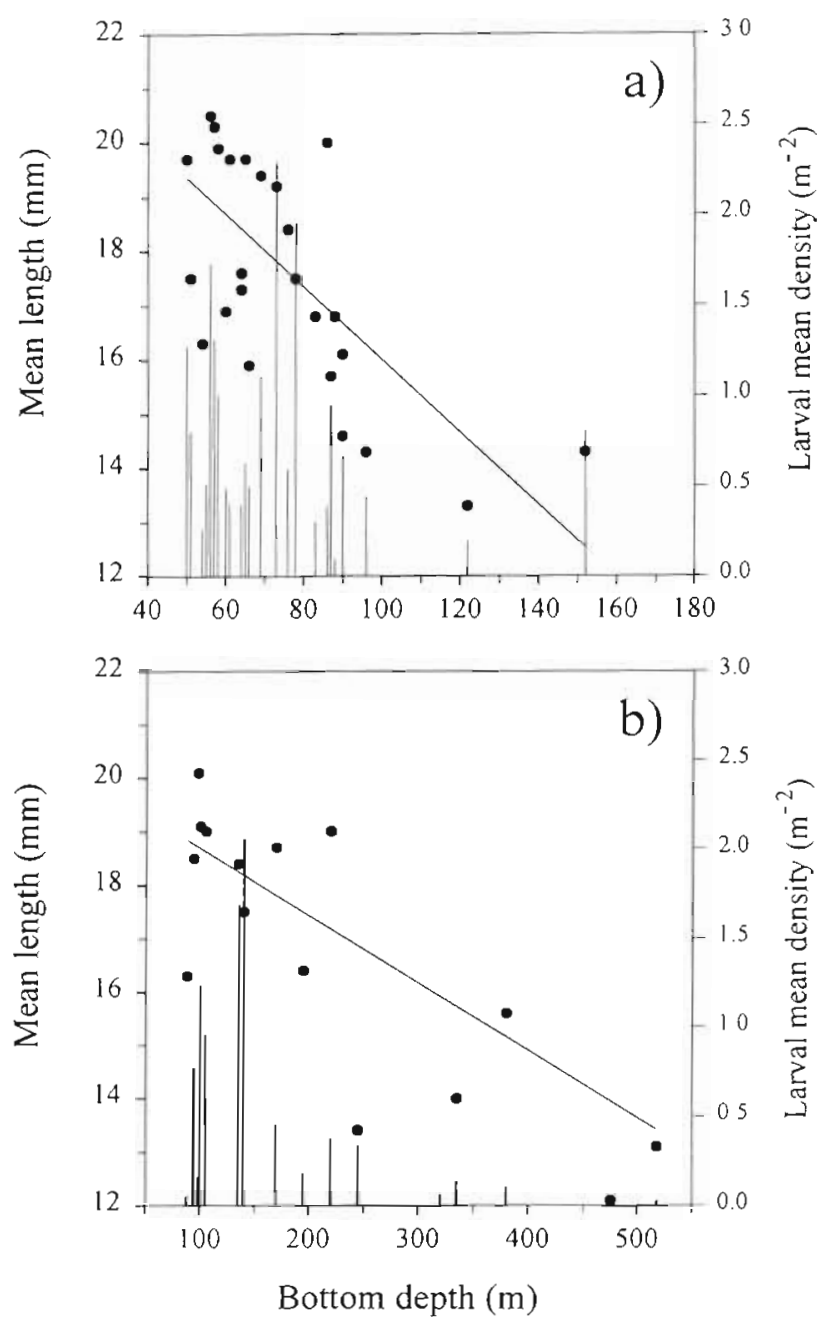

Fig. 9. Gadus morhua. Variation in mean length $(\bullet$ in $\mathrm{mm}$ ) and mean density (bars, in no. $\mathrm{m}^{-2}$ ) of cod across a range of bottom depths. Regression line shown for mean length versus depth. Variation in (a) a northwestern and (b) a northeastern area respectively are shown; see text.

in June (Munk unpubl. results) which indicated a degradation of the distinctness of the frontal zone. Satellite images of this area analysed by Holligan et al. (1989) show a band of elevated surface chlorophyll levels (probably coinciding with a frontal zone) extending along the shelf slope from the Skagerrak towards Ling Bank, further to the northwest. Observations made in the period May 2 to 17, 1980 (Holligan et al. 1989, Figs. 68 to 69) exemplify, however, how rapidly sea surface structure (here measured by chlorophyll concentrations) can change in the late spring.

The formation of a shelf break front was evident off the Danish coast, whereas a frontal zone of the same distinctness was not formed above the slope off the Norwegian coast. The dissimilarity has it background in the bathymetry and the water circulation of the area
(Rohde 1992). The slope off the Norwegian coast is much steeper than off Denmark, and the current system is dominated by the fresh water of the Norwegian Coastal Current (NCC). Off Norway the primary production was enhanced in the halocline of the NCC (at about 10 to $15 \mathrm{~m}$ depth), but we observed no obvious enhancement further down the water column. Conversely, off Denmark the primary production was enhanced throughout most of the water column. Due to the major current system of the North Sea, inflow of shelf water is found along the shelf slope off Denmark. This inflow leads to frontogenesis and to entrainment of deep nutrient-rich water into surface water (Rohde 1992).

\section{Cod larvae at the front}

While the correspondence between position of coastal tidal fronts and distribution of fish larvae is widely acknowledged (e.g. Nakata 1989, Fortier et al. 1992, Munk \& Nielsen 1994), less emphasis has been put on the relationship between larvae and hydrographic fronts of the oceanic type. There are, however, examples of concurrence at oceanic upwelling fronts off the coast of California, USA (Lasker 1981), Spain (Chesney \& Alonso-Noval 1989) and South Africa (Shelton \& Hutchings 1982). In the case of the retrograde type of oceanic fronts, examples of an association to larvae are found off Iceland (Herra 1989) and Canada (Taggart et al. 1989). In a number of studies the distribution of cod larvae has been traced to areas close to the shelf slope, at 60 to $120 \mathrm{~m}$ isobaths re.g. Ellertsen et al. 1984, Lough 1984, Suthers \& Frank 1989), and while these areas are apt for establishment of shelf break fronts, these findings indicate that our observation of a connection between fronts and cod distribution represents a more general phenomenon.

One of our goals was to assess the distinctness of distributional groups of larval/juvenile cod across the area. In the southern Kattegat we found a group of cod larvae that was distinct both in size and distributional characteristics whereas in the remaining part of the investigation area the distribution of cod was more or less coherent. Along-front we observed a continuous band of cod at high densities, and no segregation of groups was evident. When distributed in the areas of the main inflow of North Sea water to the Skagerrak, some of the larvae probably will drift along the slope towards the northeast. Advection by this current might explain the coherency of the along-front distribution, and opens the possibility that all larvae originate from a common spawning ground in the North Sea. However, the variation in mean lengths across the investigation area did not support this possibility. While the 
duration of egg/larval drift from the North Sea to the inner Skagerrak would be at least $10 \mathrm{~d}$ (distance: $220 \mathrm{~km}$, maximal residual speed of the slope current: $30 \mathrm{~m} \mathrm{~s}^{-1}$; Danielsen et al. 1994), we would expect an evident increase in mean length along the route. A slight increase in mean length was observed in the western part of Skagerrak, but some of the larvae in the inner Skagerrak were as small as those in the North Sea.

\section{Concentration of cod}

The marked peak in density of cod across the front contrast the more evenly distribution in the alongfront direction. How are such cross-frontal gradients established and retained? Possible mechanisms are: (1) spawning of cod directly in the frontal zone, (2) directed horizontal swimming by the larvae/juveniles, or (3) concentration processes due to convergence of watermasses.

If cod had spawned directly in the frontal zone, the age and size of larvae would increase from the centre of spawning to peripheral areas because of variation in spawning time and the dispersal/drift of eggs and larvae. This was not the case in our study, whereas sizes of larvae/juveniles increased in a shoreward direction, smaller (and younger, according to otolith examination; Munk unpubl. results) were found north of the front and the area of peak concentrations. These observations indicate that the observed distribution of larvae/juveniles did not simply reflect the distribution pattern of spawning intensity. Nor is it likely that larval migrations towards the front could account for the observed distribution patterns. Directed, vertical and horizontal swimming has been proposed to influence the drift of large larvae and small juvenile cod (Lough \& Bolz 1989, Werner et al. 1993), but larvae would not have the capability to cover the cross-frontal distances (kilometres) by directed horizontal swimming only.

Hydrographic processes are probably the primary factors in the concentration process of larval/juvenile fish. The density structure of the water column in a frontal zone and the energy input from tide and wind result in cross-shelf converging and diverging processes (Moors et al. 1978, Coachman 1982, Rohde 1992). Thus, planktonic organisms could be conveyed towards the frontal zone and, if they actively oppose the divergence there, for example by positive phototactic movements in a downwelling situation, they would aggregate. A study modelling larval drift by Werner et al. (1993) demonstrated the potential importance of the Ekman layer convergence near a shelf break. These authors found that this process provided a mechanism for larvae to exit from a surface drift off
Georges Bank. During a number of other studies concentration of plankton has been observed and an aggregation based on convergence has been proposed; this is the case for invertebrate zooplankton (Herman et al. 1981, Zeldis \& Jillett 1982) and for fish larvae/juveniles (Olson \& Backus 1985, Iwatsuki et al. 1989, Nakata 1989).

Aspects of buoyancy could also play a role in the aggregation process of cod larvae. Neutral buoyancy of small Atlantic cod larvae is attained at $1027.5 \mathrm{~kg} \mathrm{~m}^{-3}$ (Ellertsen et al. 1980), which means that passive larvae (at night) are apt to be distributed around isopycnals of that magnitude. The front in our study covered a restricted range of water densities, 1027.3 to $1027.6 \mathrm{~kg}$ $\mathrm{m}^{-3}$, and in that area the isopycnals diverge vertically. Thus, eggs and larvae conveyed towards the shelf in surface water would be downwelled at the front whereas offshelf drift of cod in the deeper water would lead to an upward movement at the front. Factors that influence buoyancy such as larval condition (Sclafani et al. 1993) and swimbladder inflation/deflation (Hoss et al. 1989) could also be of importance in the aggregation process.

The concentration of cod larvae, specifically in the frontal zone, may be favorable both with respect to enhancement of food availability and ensurance of an initial cohesion of the population. We suspect that the cod, through its spawning behaviour, aim at a match between the offspring and the hydrographic front. However, the hydrographic fronts are very dynamic, influenced by wind stress and apt to vary within a season and between years. Thus, there is the risk that in a given year, the match between cod larvae and the front (in time and space) would be out of phase, leading to increased dispersion of larvae, to reduced growth and survival and, consequently, to poor recruitment to the cod stock.

\section{LITERATURE CITED}

Brander KM (1994) The location and timing of cod spawning around the British Isles. ICES J mar Sci 51:71-89

Campana SE, Smith SJ, Hurley PCF (1989) An age-structured index of cod larval drift and retention in the waters off southwest Nova Scotia. Rapp P-v Réun Cons int Explor Mer 191:50-62

Chesney EJ, Alonso-Noval M (1989) Coastal upwelling and the early life history of sardines (Sardina pilchardus) along the Galician coast of Spain. Rapp P-v Reun Cons int Explor Mer 191:63-69

Coachman LK (1982) Flow convergence over a broad, flat continental shelf. Cont Shelf Res 1(1):1-14

Daan N (1978) Changes in cod stocks and cod fisheries in the North Sea. Rapp P-v Réun Cons int Explor Mer 172:39-57

Danielsen DS, Edler L, Fonselius S, Hernroth L, Ostrowski M, Svendsen E, Talsepp L (1995) Oceanographic variability in Skagerrak/northern Kattegat, May-June 1990. ICES $\mathrm{J}$ mar Biol (in press) 
Doyle MJ, Ryan TA (1989) Spatial patterns in a coastal ichthyoplankton community southwest of Ireland. Rapp P-V Réun Cons int Explor Mer 191:70-84

Ellertsen B, Fossum P, Solemdal P, Sundby S (1989) Relation between tempera ture and survival of eggs and first feeding larvae of northeast Arctic cod (Gadus morhua L.). Rapp P-v Réun Cons int Explor Mer 199:209-219

Ellertsen B, Fossum P, Solemdal P, Sundby S, Tilseth S (1984) A case study on the distribution of cod larvae and availability of prey organisms in relation to physical processes in Lofoten. Flødevigen rapportser 1:453-477

Ellertsen B, Solemdal P. Strømme T, Sundby S, Tilseth $\mathrm{S}$, Westgárd T (1981) Spawning period, transport and dispersal of eggs from the spawning area of arcto-norwegian cod (Gadus morhua L.). Rapp P-v Réun Cons int Explor Mer 178:260-267

Ellertsen B, Solemdal P, Strømme T, Tilseth S, Westgård T (1980) Some biological aspects of cod larvae (Gadus morhua L.). FiskDir Skr Ser Havunders 17:29-47

Fortier L, Levasseur ME, Drolet R, Therriault JC (1992) Export production and the distribution of fish larvae and their prey in a coastal jet frontal region. Mar Ecol Prog Ser 85:203-218

Graham M, Carruthers JN (1925) The distribution of pelagic stages of the cod in the North Sea in 1928 in relation to the currents. Fishery Invest London $28(6): 1-31$

Herman AW, Sameoto DD, Longhurst AR (1981) Vertical and horizontal distribution patterns of copepods near the shelf break south of Nova Scotia. Can J Fish Aquat Sci 38(9): $1065-1076$

Herra $T$ (1989) Larval redfish drift migration in relation to hydrographic features. Rapp P-v Réun Cons int Explor Mer 191:92-99

Holligan PM, Aarup T, Groom SB (1989) The North Sea satellite colour atlas. Cont Shelf Res 9(8):667-765

Hoss DE, Checkley DM, Settle LR (1989) Diurnal buoyancy changes in the larval Atlantic menhaden (Brevoortia tyrannus). Rapp P-v Réun Cons int Explor Mer 191: $105-111$

Hurley PCF, Campana SE (1989) Distribution and abundance of haddock (Melanogrammus aeglefinus) and Atlantic cod (Gadus morhua) eggs and larvae in the waters off southwest Nova Scotia. Can J Fish Aquat Sci 46:103-112

I watsuki $Y$, Nakata $H$, Hirano R (1989) The thermohaline front in relation to fish larvae. Rapp P-v Réun Cons int Explor Mer 191:119-126

Jeffrey SW, Humprey GF (1975) New spectrophotometric equations for determining chlorophylls $a, b, c_{11}$ and $c_{2}$ in higher plants, algae and natural phytoplankton. Biochem Physiol Pflanz 167: 191-194

Jonsson $E$ (1982) A survey of spawning and reproduction of the Icelandic cod. Rit Fiskedeildar 6(2):1-45

Kiørboe T, Munk P, Richardson K, Christensen V, Paulsen $\mathrm{H}$ (1988) Plankton dynamics and larval herring growth, drift and survival in a frontal area. Mar Ecol Prog Ser 44: $205-219$

Kiørboe T, Nielsen TG (1990) Effect of wind stress on vertical water column structure, phytoplankton growth and productivity of planktonic copepods. In: Barbes M, Gibson RN (eds) Trophic interactions in the marine environment. Proc 24th Eur Mar Biol Symp. Aberdeen University Press, Aberdeen, p 28-40

Lasker $\mathrm{R}$ (1981) Factors contributing to variable recruitment of the northern anchovy (Engraulis mordax) in the California Current: contrasting years 1975 through 1978. Rapp P-v Réun Cons int Explor Mer 178:375-388

Lough RG (1984) Larval fish trophodynamic studies on
Georges Bank: sampling strategy and initial results. In Dahl E, Danielsen DS, Moksness E, Solemdal P (eds) The propagation of cod Gadus morhua L. Flødevigen rapportser 1:395-434

Lough RG, Bolz GR (1989) The movement of cod and haddock larvae onto the shoals of Georges Bank. J Fish Biol 35 (Suppl A):71-79

Marra J, Houghton RW, Garside C (1990) Phytoplankton growth at the shelf break front in the Middle Atlantic Bight. J mar Res 48:851-868

Moors CNK, Flagg CN, Boicourt WC (1978) Prograde and retrograde fronts. In: Bowman MJ, Esaias WE (eds) Oceanic fronts in coastal processes. Springer-Verlag, Berlin, p 43-58

Munk P (1993a) Describing the distribution and abundance of small 0-group cod using ring-net sampling and echo-integration. Comm Meet Int Coun Explor Sea CM-ICES/G:40

Munk P (1993b) Differential growth of larval sprat Sprattus sprattus across a tidal front in the eastern North Sea. Mar Ecol Prog Ser 99:17-27

Munk P, Nielsen TG (1994) Trophodynamics of the plankton community at Dogger Bank: predatory impact by larval fish. J Plankton Res 16(9):1225-1245

Nakata H (1989) Transport and distribution of fish eggs and larvae in the vicinity of coastal fronts. Rapp P-v Réun Cons int Explor Mer 191:153-159

Nielsen GN, Løkkegaard B, Richardson $K_{\text {, Pedersen FB }}$ Hansen L (1993) Structure of plankton communities in the Dogger Bank area (North Sea) during a stratified situation. Mar Ecol Prog Ser 95:115-131

Olson DB, Backus RH (1985) The concentrating of organısms at fronts: a cold water fish and a warm-core Gulf Stream ring. J mar Res 43(1):113-137

Poulsen EM (1931) Biological investigations upon the cod in Danish waters. Meddr Komn Darm Fisk-og Havunders Ser Fiskeri 9(1): 1-148

Rohde J (1992) Studies of currents and mixing in the Skagerrak. Doctoral Thesis, Dept of Oceanography, University of Gothenburg, Sweden

Schmidt J (1905) The pelagic post-larval stages of the Atlantic species of Gadus. A monograph with 3 plates and 16 figures in the text. Meddr Komn Danm Fisk- og Havunders Ser Fiskeri 1(4): $1-77$

Sclafani M, Taggart CT, Thompson KR (1993) Condition, buoyancy and the distribution of larval fish: implications for vertical distribution and retention. J Plankton Res 15(4):413-435

Shelton PA, Hutchings L (1982) Transport of anchovy, Engraulis capensis Gilchrist, eggs and early larvae by a frontal jet current. J Cons int Explor Mer CIEM 40(2): $185-198$

Suthers IM. Frank KT (1989) Inter-annual distributions of larval and pelagic juvenile cod (Gadus morhua) in southwestern Nova Scotia determined with two different gear types. Can J Aquat Sci 46:591-602

Taggart CT, Drinkwater KF, Frank KT, McRuer J, LaRouche P (1989) Larval fish, zooplankton community structure, and physical dynamics at a tidal front. Rapp P-v Réun Cons int Explor Mer 191:184-194

Werner FE, Page FH, Lynch DR, Loder JW, Lough RG, Perry RI, Greenberg DA, Sinclair MM (1993) Influences of mean advection and simple behaviour on the distribution of cod and haddock early life stages on Georges Bank. Fish Oceanogr 2(2):43-64

Zeldis JR, Jillett JB (1982) Aggregation of pelagic Munida gregaria (Fabricus) (Decapoda, Anomura) by coastal fronts and internal waves. J Plankton Res 4(4):839- 858 